\title{
Vitamin D in Patients With Duchenne Muscular Dystrophy
}

\section{Duchenne Muskuler Distrofili Hastalarda Vitamin D Düzeyi}

\author{
Filiz Meryem Sertpoyraz', Bedile Irem Tiftikcioglu², Figen Baydan³ , Bakiye Tunçay4, \\ Oya Halıcıŏglu Baltalı ${ }^{5}$
}

${ }^{1}$ FTR Kliniği ve Nöromuskuler Hastalıklar Birimi, SBÜ, İzmir Tepecik SUAM, İzmir, Turkey ${ }^{2}$ Nöroloji Kliniği, Başkent Üniversitesi, Zübeyde Hanım Uygulama ve Araştırma Merkezi, İzmir, Turkey ${ }^{3}$ Çocuk Nöroloji Kliniği ve Nöromuskuler Hastalıklar Birimi, SBÜ, İzmir Tepecik SUAM, İzmir, Turkey ${ }^{4}$ Nöromuskuler Hastalıklar Birimi, SBÜ, İzmir Tepecik SUAM, İzmir,Turkey ${ }^{5}$ Çocuk Kliniği, SBÜ, İzmir Tepecik SUAM, İzmir, Turkey

\begin{abstract}
Objectives: Duchenne Muscular Dystrophy (DMD) is one of the neuromuscular junction dystrophies, characterized by deficiency of dystrophin and inherited as an X-linked recessive trait. It has a progressive nature, and results in loss of ambulation and death. Poor bone-marrow health is an important issue in terms of morbidity in DMD. Vitamin D is an important pre-prohormone related to bone health. Although steroids used in treatment of DMD are effective on progression of the disease they have adverse effects on bone heatlh and $25(\mathrm{OH})$-vitamin D (vitamin D) levels. We aimed in the present study to investigate levels of vitamin $\mathrm{D}$ and its relationship with steroid use and ambulation in the patients with DMD.

Material and Metods: The present study is a case-control study including 96 male patients aged between 2 to 18 years with diagnosis of DMD and 48 healthy volunteers with matching gender and age distribution.

Results: Deficiency or insufficiency of vitamin D level was found in $95.83 \%$ of the patients with DMD. The patients with DMD were compared to the healthy volunteers and significantly lower level of vitamin $\mathrm{D}$ was found in the group of patients $(\mathrm{p}=0.003)$. No significant difference was found in levels of vitamin $\mathrm{D}$ between the patients with DMD who were using steroids and those not using steroids and between the patient who were ambulated or not ambulated $(\mathrm{p}=0.741$ and $\mathrm{p}=0.785)$.

Conclusion: Majority of the patients with DMD had deficient or insufficient level of vitamin D. Thus, in the terms of protecting bone health it is important to assess level of vitamin D regularly from the early stages of the disease and during the routine controls, to implement additional treatments in the case of deficiency or insufficiency.

Key words: Duchenne Muscular Dystrophy, Vitamin D, Steroid
\end{abstract}

Öz

Amaç: Duchenne Musküler Distrofi (DMD), kavşak tipi distrofilerden olup X’e bağlı resesif geçen, distrofin eksikliği karakterize kas hastalığıdır. İlerleyicidir, ambulasyon kaybı ve erken dönemde ölümlere yol açar. Zayıf kemik sağlığı DMD'de morbidite açısından önemli bir sorundur. Vitamin D, kemik sağlığı açısından önemli bir preprohormondur. DMD tedavisinde kullanılan steroidlerin hastalığın progresyonu üzerinde etkin tedavisi olmasına rağmen kemik sağlığı ve vitamin $D$ üzerinde olumsuz etkileri bulunmaktadır. DMD'li hastalarda serum $25(\mathrm{OH})$ vitamin D (vitamin D) düzeylerini, vitamin D'nin steroid kullanımı ve ambulasyonla ilișkisini değerlendirmeyi amaçlandık.

Materyal-Metot: Vaka kontrol olan çalışmaya doksan altı kesin DMD tanısı almıș, 2-18 yaş, erkek hasta ve kırk sekiz benzer yaş ortalaması ve cinsiyette sağlıklı gönüllüler alındı.

Bulgular: DMD'li hastalarda \%95,83 oranında vitamin D düzeylerinde eksiklik - yetersizlik saptandı. DMD 'li hastalar ile sağlıklı gönüllüler karşılaştırıldı, vitamin D düzeylerinde hasta grubunda anlamlı düşüklük saptandı $(\mathrm{p}=0.003)$. DMD'li steroid alan ve almayanlar ile ambulasyonu olan ve olmayan hastalar arasında vitamin D düzeyleri açısından fark saptanmadı ( $\mathrm{p}=0.741$ ve $\mathrm{p}=0.785)$.

Sonuç: DMD’li hastalarda, yüksek oranda vitamin D düzeylerinde eksiklik-yetersizlik mevcuttu. Bu nedenle D vitamin düzeylerinin erken dönemden itibaren ve rutin kontrollerde düzenli değerlendirilmesi ve eksiklik-yetersizliğinde ilave tedavilerinin yapılması kemik sağlığını korumak açısından oldukça önemlidir.

Anahtar Kelimeler: Duchenne Muskuler Distrofi, vitamin D, Steroid 
Yazıșma Adresi / Correspondence:

Dr. Filiz Meryem Sertpoyraz

e-mail: dr.fms7o@gmail.com

Date of submission: 26.02.2019

Date of admission: 16.05.2019

\section{Introduction}

Duchenne Muscular Dystrophy (DMD) is one of the muscular dystrophies of juinction type; it is X-linked recessive disease being seen in 1 in 3600 to 6000 male births. Absence and defect of dystrophin protein develops due to mutation in the Xp21 dystrophin gene, followed by instability and degeneration in the muscle fibers. The progressive muscular weakness leads to loss of independent ambulation and early death at around age of $13 .{ }^{1,2}$ Use of corticosteroids is considered as gold-standard in its treatment. ${ }^{1}$ Although use of steroids is effective in protecting muscle strength, improving walking and survival, decreasing rate of development of scoliosis, and keeping the respiratory function stable it increases risk for osteoporosis and bone fractures.3,4 Normally, the bone is a dynamic tissue with osteoblastic and osteoclastic activity being in balance. Health of bone is maintained this way. Factors affecting bone health include genetics, nutrition, physical activity and muscle strength, age, and the hormones. Corticosteroid treatment impacts bone destruction both directly and indirectly. It suppresses release of growth hormone and inhibits synthesis of insulinlike growth factor-I. As a consequence of inhibition of the growth factors, number and activity of the osteoblast decreases while the osteoclasts are directly activated. Additionally, calcium absorption from intestinal mucosal cells decreases and excretion of calcium and phosphorus from the kidneys increase. Consequently developing hypocalcemia causes secondary hyperparathyroidism. Turnover rate of the bone increases, but there is insufficient bone synthesis because the osteoblasts are suppressed. Eventually, bone resorption and osteoporosis develop. ${ }^{4}$ Another factor affecting bone health is Vitamin D. Vitamin D is a hormone of sekosteroid type synthesized in the skin in the presence of sunlight. Its main source is synthesis in the skin following direct exposure to the sunlight but it is present at small amount in the diet and food supplements. ${ }^{5}$ Vitamin $\mathrm{D}$ is required for absorption of calcium from the kidneys and intestines. It acts via its widespread receptors in the muscles and bones. Deficiency of Vitamin D causes irregularity in osteoblastic function in the bone, disorder in calcium metabolism, and increase in risk for death. ${ }^{6,7}$ Severe deficiency of Vitamin D causes rickets and osteomalasia leading to deformities in the soft bone whereas its less severe form causes increased resorption of bone, osteoporosis and risk for fracture due to increased serum level of parathyroid hormone. ${ }^{8}$ Steroids have mixed effects on the bone. They are required for normal bone health at the physiological doses while they are the most common cause of weakened bone and secondary osteoporosis at high doses. ${ }^{9,10}$ Clinically, it has reported that they cause loss of bone by $\% 12$ in the first few months of treatment and the loss continues at rate of 2 to $5 \%$ annually. ${ }^{11}$ Poor bone health is a significant condition adversely impacting quality of life of the patients with DMD due to bone pain, osteopenia, fracture and increase in the risk for fractures because of osteoporosis..$^{12}$ Detection of level of vitamin $\mathrm{D}$ effective of bone health and implementing treatment in the case of its deficiency are of importance. 
Thus, we aimed to determine the vitamin D levels in DMD patients, compare with healthy volunteers, and asses their relationship to steroid use and ambulation in DMD patients.

\section{Materials and Metods}

Case-control study

Medical files of 96 male patients being followed with definitive diagnosis of DMD in the Department of Neuromuscular Diseases, Izmir Tepecik Education and Training Hospital during March, April and May of 2017 and 2018 were reviewed. Additionally, 48 healthy young male volunteers were also included in the study.

All patients and/or relatives gave informed written consent and read Helsinki Patient Rights Declaration. Approval for the study was taken from the local Ethics Committee at Izmir Tepecik Education and Training Hospital (Approval Number: 2013-44/1). The study included the male patients with definitive diagnosis of DMD consistent based clinical, laboratory, genetic and/or biopsy findings who were between 2 and 18 years old.

The controls included age- and gender-matched healthy children visiting the pediatrics service. Patients and controls who did not sign the informed consent form or did use vitamin D supplements were not included.

Demographic data of the patients (age, duration of diagnosis, educational level), functional activity level (ambulation status), steroid use, and history of fractures, blood level of $25(\mathrm{OH})$-vitamin $\mathrm{D}$, calcium, phosphorus, alkali phosphatase, and parathyroid hormone were recorded from their files.

The patients with DMD were divided in 5 groups based on their functional activity level according to the DMD Staging by DMD Care Considerations Working Group (Table 1).

Stages 1, 2 and 3 were considered as ambulatory, and Stages 4 and 5 as non-ambulatory. Status of vitamin D was assessed with electrohemiluminescent method by measuring the serum level of $25(\mathrm{OH})$-vitamin D using COBAS 411 (Roche Diagnostics).

Half-life of $25(\mathrm{OH})$-vitamin D is 2 to 3 weeks. 1,25-dihydroxy Vitamin D doesn't yield good information on level of vitamin $\mathrm{D}$ because of its short half-life of 4 hours and its low concentration of blood. Thus, level of $25(\mathrm{OH})$-vitamin $\mathrm{D}$ is used in diagnosing deficiency of vitamin D.

Levels of vitamin D were grouped as follows: $>30 \mathrm{ng} / \mathrm{mL}$, sufficient; 21-30 ng/mL, insufficiency; <20 ng/mL, deficiency; and <10 ng/mL, severe deficiency. ${ }^{13,14}$

Serum vitamin D levels were evaluated at the time of initial application of the patients and healthy volunteers. Vitamin D levels were grouped as deficient, insufficient, and sufficient. The patients with DMD were divided into two groups as those with and without steroids and those with and without mobility. Average vitamin D levels of these groups were compared.

Statistical Analysis

Statistical analysis was performed using IBM SPSS Statistics v.23.o (Statistical Package for Social Sciences, IBM Corp., NY, USA). Categorical variables were compared using 
Chi-square test (or Fisher's exact test, where appropriate). Continuous variables were compared using Mann-Whitney $U$ test between the patient groups. The $p$-values $<0.05$ were considered as significant.

Table 1. The DMD staging by DMD Care Considerations Working Group.

\begin{tabular}{|l|l|}
\hline Stage & Symptoms / Diagnostic criteria \\
\hline 1. Presymptomatic & $\begin{array}{l}\text { - Can be diagnosed if they have high CK levels or } \\
\text { positive family history } \\
\text { - A developmental delay might be present but no gait } \\
\text { disturbance }\end{array}$ \\
\hline 2. Early ambulatory & $\begin{array}{l}\text { - Gower's sign } \\
\text { - Waddling gait } \\
\text { - Might have toe walking } \\
\text { - Can climb stairs }\end{array}$ \\
\hline 3. Late ambulatory & $\begin{array}{l}\text { - Increased walking difficulty } \\
\text { - Loss of ability to climb stairs and get up from ground }\end{array}$ \\
\hline 4. Early non-ambulatory & $\begin{array}{l}\text { - Wheelchair use } \\
\text { - Can self-propel for a while } \\
\text { - Can maintain posture } \\
\text { - Might develop scoliosis }\end{array}$ \\
\hline 5. Late non-ambulatory & $\begin{array}{l}\text { - Wheelchair use } \\
\text { - Increasingly limited upper extremity function and } \\
\text { postural maintenance }\end{array}$ \\
\hline
\end{tabular}

CK: Creatine Kinase, DMD: Duchenne Muscular Dystrophy

\section{Results}

All patients were male and mean age was $11.24 \pm 5.41$ years (range: $2-18$ years). Mean duration of diagnosis was $7.24 \pm 4.85$ years. Mean age of the healthy volunteers was $11.85 \pm 3.51(2-18)$ years. Demographic data of the patients with DMD are given and their laboratory data in the Table 2.

There was no significant difference in mean age between the group of patients and healthy controls $(p=0.327)$. Significant difference was found in serum level of vitamin $\mathrm{D}$ between the group of patients and healthy controls $(\mathrm{p}=0.003)$ (Table 3$)$.

Two patients with history of fracture were using steroid for more than 6o months and had severe deficiency of vitamin D. Of the patients, 46 (48\%) were ambulatory and 50 (52\%) were non-ambulatory.

No significant difference was found in levels of vitamin $D$ between the patients with DMD who were using steroids and those not using steroids $(\mathrm{p}=0.741)$

No significant difference was found in serum level of vitamin $\mathrm{D}$ level between the ambulatory and non-ambulatory patients with DMD ( $\mathrm{p}=0.785)$.

Two patients with fracture of long bone (femur and humerus) had history of steroid use. Both patients had severe deficiency of vitamin D. 
When level of vitamin D of the patients was evaluated, $82(85.41 \%)$ patients had deficiency, 10 (10.42\%) had insufficiency. Level of vitamin D was sufficient only in 4 (4.17\%) patients (Table 4$)$.

Table 2. Demographic and laboratory data for the patients with DMD.

\begin{tabular}{|c|c|}
\hline Variable & n (\%) \\
\hline \multicolumn{2}{|l|}{ Education } \\
\hline No literacy & $18(18.75)$ \\
\hline Primary education & $52(54.16)$ \\
\hline Secondary & $25(26.04)$ \\
\hline University & $1(1.05)$ \\
\hline \multicolumn{2}{|l|}{ Kinship } \\
\hline No & $77(80.21)$ \\
\hline Yes & $19(19.79)$ \\
\hline \multicolumn{2}{|l|}{ Functional Activity Levels } \\
\hline Ambulatory & $46(47.92)$ \\
\hline Non- Ambulatory & $50(52.08)$ \\
\hline \multicolumn{2}{|l|}{ Steroid Used } \\
\hline No & $24(25.26)$ \\
\hline Yes & $71(74.74)$ \\
\hline \multicolumn{2}{|l|}{ Bone Fracture story } \\
\hline No & $94(97.92)$ \\
\hline Yes & $2(2.08)$ \\
\hline Serum Levels of DMD Patients & Mean \pm SD (Min.-Max.) \\
\hline Vitamin D (ng/mL) & $13.62 \pm 7.33(3-36)$ \\
\hline Calcium (8.6-10mgr/dL) & $9.9 \pm 0.5(8.5-11.0)$ \\
\hline Parathyroid Hormone (15-45pg/mL) & $42.4 \pm 18.5(13-109)$ \\
\hline Creatine Kinase $(<170 \mathrm{OU} / \mathrm{L})$ & $7113.8 \pm 6234.0(84.0-24110)$ \\
\hline Lactate Dehydrogenase (135-214 U/L) & $695 \cdot 5 \pm 418.3(191-1801)$ \\
\hline
\end{tabular}

DMD: Duchenne Muscular Dystrophy, SD: Standard Deviation

\section{Discussion}

We assessed relationship of level of Vitamin D with steroid use and ambulation in the patients with DMD for whom bone health is of importance.

There are many factors adversely affecting bone health in DMD. 5 These include progressive muscle weakness, cytokines released due to the inflammatory response in the muscles deficient of dystrophin, activation of osteoclastogenesis along with altered muscle metabolism, delayed puberty with decreased sex steroids due to corticosteroids, altered osteoblastic formation/mineralization of bone, poor calcium and vitamin D absorption, alterations in calcium homeostasis due to immobilization, and reduced exposure to sunlight. ${ }^{5}$ 
Table 3. Comparison of DMD and control groups.

\begin{tabular}{|l|c|c|c|}
\hline & DMD & Control & p-value \\
\hline Age $($ Years, Mean \pm SD) & $11.24 \pm 5.41$ & $11.85 \pm 3.51$ & 0.327 \\
\hline Gender $($ Male /Female) & $96 / 0$ & $48 / 0$ & - \\
\hline Vitamin D $(\mathrm{ng} / \mathrm{mL}$, Mean \pm SD) & $13.62 \pm 7.33$ & $17.97 \pm 8.36$ & $\boldsymbol{o . o o}$ \\
\hline
\end{tabular}

DMD: Duchenne Muscular Dystrophy, SD: Standard Deviation

${ }^{*} \mathrm{p}<0.05$ statistically significant.

Available evidence has emphasized that recent DMD studies have focused on vitamin D hypovitaminosis, abnormal calcium metabolism, increased risk of fracture. Vitamin D deficiency increases blood parathormone levels and triggers osteoporosis, thereby increasing the risk of falls and fractures. When vitamin D deficiency is treated, it is emphasized that it may reduce the risk of fracture. ${ }^{15}$ In the present study, both the patients with DMD and healthy volunteers had insufficient and deficient levels of vitamin D.

Table 4. Vitamin D levels of in patients with Duchenne Muscular Dystrophy.

\begin{tabular}{|l|c|c|}
\hline & n & $\%$ \\
\hline Severe deficiency $(<10 \mathrm{ng} / \mathrm{mL})$ & 39 & 40.62 \\
\hline Deficiency $(11-20 \mathrm{ng} / \mathrm{mL})$ & 43 & 44.79 \\
\hline Insufficiency $(21-30 \mathrm{ng} / \mathrm{mL})$ & 10 & 10.42 \\
\hline Normal $(30 \mathrm{ng} / \mathrm{mL}<)$ & 4 & 4.17 \\
\hline Total & 96 & 100 \\
\hline
\end{tabular}

n: numbers of patient \%: percentage

In a study assessing prevalence of level of vitamin D in children in our country, Dogan et al. noted that up to $61 \%$ of the children had insufficiency-deficiency of vitamin D with the highest rate of prevalence being in the age group of $13-17$ years. ${ }^{16}$

In the current study, we found that $95.8 \%$ of the patients with DMD had deficient level of vitamin D. Level of vitamin D was sufficient only in $4 \%$ of the patients.

Serum level of vitamin D was significantly lower in the patients with DMD comparted to the healthy group of volunteers of the same sex.

The research has highlighted that deficiency of vitamin $\mathrm{D}$ is a common problem in the patients with DMD. ${ }^{16,17}$ Mason et al. evaluated level of vitamin D in 157 patients with DMD and found insufficiency in $78 \%$ and deficiency in $15 \%$ of them. ${ }^{17}$

Using corticosteroids has adverse effects on bone and level of vitamin D. Current therapeutic protocols especially note that calcium and vitamin D should be added to treatment of the patients with DMD using corticosteroids. ${ }^{18}$

In the present study, although the groups using and not using corticosteroid has deficient levels of vitamin $\mathrm{D}$, there was no significant difference between two groups in terms of level of vitamin D. 
In line with the present study, Bianchi et al. assessed bone mineral density and bone metabolism in 32 patients with DMD and compared the patients using and not using corticosteroids. They found that level of vitamin $\mathrm{D}$ and bone mineral density were low in both groups and noted that lowness of bone mineral density was more prominent in the group using corticosteroids. They also noted that daily supplementation of vitamin $\mathrm{D}$ and calcium could increase bone mineral density up to $65 \%$ and improved parameters of bone turnover. ${ }^{19}$

Alshaikh et al. evaluated serum levels of $25(\mathrm{OH})$-vitamin $\mathrm{D}$ in the patients with DMD receiving $(n=463)$ and not receiving $(n=154)$. They found deficient level of vitamin $D$ in $70 \%$ of the patients in the group receiving vitamin $\mathrm{D}$ and in $52 \%$ of the patients in the group not receiving vitamin D. They noted that daily doses of 400 IU and 800 IU they used failed to achieve optimal dose and that sufficient levels could be achieved at rate of up to $64 \%$ by treatment of vitamin D at dose of 1000 to 1500 IU following the loading dose. ${ }^{20}$ In the present study, two patients had history of fracture in the lower limb after falling down from height. It was found that both patients had used steroids for more than five years, had severely deficient level of vitamin D lower than $10 \mathrm{ng} / \mathrm{mL}$, and had fractures in the femur and tibia following fall. They had lost their ability to walk after the cast period and they achieved ambulation with wheel chair.

There is lower bone mineral density in the muscular dystrophies than in the healthy individuals. Accompanying deficiency of vitamin D causes deficient mineralizasyon, deformities, and osteoporosis and increased risk for fracture due to increased serum level of parathyroid hormone. Falls are the most common cause of fracture in DMD.4,21

Perera et al. retrospectively assessed rate of fractures and level of vitamin D in 48 patients with DMD. They suggested that rate of fracture increased with advanced age and that $84 \%$ of the patients had deficiency of vitamin D and it should be optimized with supplementation of vitamin D prior to decrease of ambulation. ${ }^{15}$ Fractures occur in $21-44 \%$ of the patients with DMD. Long bone fractures are more common in the younger ambulatory male patients following falls whereas vertebral fractures are common in the non-ambulatory patients and in those using steroids. ${ }^{4}$ Rate of fractures increase after loss of gait. ${ }^{22}$ In their case report of 378 patients with DMD, McDonald et al. reported that $21 \%$ of the patients had fractures, the fractures were most common in the age group of 8-11 years, and the most significant reason for the fractures was falls. ${ }^{23}$

In the NHANES study, risk for hip fracture was compared according to serum levels of ${ }_{25}(\mathrm{OH})$-vitamin D. Risk for hip fracture was $60 \%$ for the levels below $16 \mathrm{ng} / \mathrm{mL}, 45 \%$ for $16-20 \mathrm{ng} / \mathrm{mL}, 36 \%$ for $20-25 \mathrm{ng} / \mathrm{mL}$, and $13 \%$ for $25-30 \mathrm{ng} / \mathrm{mL}$. They reported that risk for hip fracture increased as serum level of vitamin D decreased. ${ }^{24}$ In the present study, both group of patients with and without ambulation loss had insufficient-deficient level of vitamin $\mathrm{D}$, but no significant difference existed between the groups. This may be due to the fact that rate of insufficiency-deficiency of vitamin $\mathrm{D}$ was higher in the group of patients with DMD.

In contrast to the findings of the present study, deficiency of vitamin D was more common in non-ambulatory patients with DMD. ${ }^{25}$ It was reported that the reason for this was that loss of mobilization due to progressive muscle weakness caused decreased outdoor activities and exposure to sunlight and this contributed to deficiency of vitamin $\mathrm{D}$; they also noted that adding vitamin $\mathrm{D}$ to the diet and taking 
sufficient level of dietary vitamin D improved both bone mineral density and parameters of bone turnover. ${ }^{26}$

There was significant deficiency of vitamin D in the patients with DMD compared the healthy group. Deficiency of vitamin D was found in $95,83 \%$ of the patients with DMD. No significant association was found between levels of vitamin D and loss of ambulation and steroid use in DMD patients. The reason for this was considered to be that both groups had deficiency and insufficiency of vitamin $\mathrm{D}$ at high rates. It was highly remarkable that the patients with DMD have deficient levels of vitamin D at high rates. In the terms of protecting bone health in the patients with DMD, it is important to assess level of vitamin D regularly from the early stages of the disease and during the routine controls, to implement additional treatments in the case of deficiency or insufficiency.

Authors declare that they have no conflict of interest.

\section{References}

1. Emery AE. Population frequencies of inherited neuromuscular diseases - a world survey. Neuromuscul Disord 1991;1:19-29.

2. Bushby K, Finkel R, Birnkrant DJ, Case LE, Clemens PR, Cripe L, et al. Diagnosis and management of Duchenne muscular dystrophy, part 2: implementation of multidisciplinary care. Lancet Neurol 2010;9:177-89.

3. Dubowitz V. Steroids in Duchenne muscular dystrophy. Neuromuscul Disord 2013;23:527-8.

4. Bell JM, Shields MD, Watters J, Hamilton A, Beringer T, Elliott M, et al. Interventions to prevent and treat corticosteroid-induced osteoporosis and prevent osteoporotic fractures in Duchenne muscular dystrophy. Cochrane Database Syst Rev 2017;1:CDo10899.

5. Joyce NC, Hache LP, Clemens PR. Bone health and associated metabolic complications in neuromuscular diseases. Phys Med Rehabil Clin N Am 2012;23:773-99.

6. Goltzman D. Functions of vitamin D in bone. Histochem Cell Biol 2018;149:305-12.

7. Morgenroth VH, Hache LP, Clemens PR. Insights in to bone health in Duchenne muscular dystrophy. Bonekey Rep 2012;1:9.

8. Lips P. Vitamin D physiology. Prog Biopshys Biol 2006;92:1-8.

9. Massafra UM, Migliaccio S, Bancheri C, Chiacchiararelli F, Fantini F, Leoni F, et al. Approach in glucocorticoid induced osteoporosis prevention: Results from the Italian multicenter observational study. J Endocrinol Invest 2013;36:92-6.

10. Biggar WD, Bachrach LK, Henderson RC, Kalkwarf H, Plotkin H, Wong BL. Bone health in Duchenne muscular dystrophy: a workshop report from the meeting in Cincinnati, Ohio, July 8 , 2004. Neuromuscul Disord 2005;15:80-5.

11. Kim HJ. New understanding of glucocorticoid action in bone cells. BMB Rep 2010;43:524-529. DOI:10.5483/BMBRep.2010.43.8.524

12. James KA, Cunniff C, Apkon SD, Mathews K, Lu Z, Holtzer C. Risk factors for first fractures among males with Duchenne or Becker muscular dystrophy. J Pediatr Orthop 2015;35:640-4.

13. Holick MF. Vitamin D deficiency. N Engl J Med 2007;357:266-81.

14. Holick MF, Binkley NC, Bischoff-Ferrari HA et al. Evaluation, treatment, and prevention of vitamin d deficiency: an Endocrine Society Clinical Practice Guideline. J Clin Endocrinol Metab 2011;96:1911-30.

15. Perera N, Sampaio H, Woodhead H, Farrar M. Fracture in Duchenne muscular dystrophy: natural history and vitamin D deficiency. J Child Neurol 2016;31:1181-7.

16. Dogan N, Colak A, Guden N, Ustuner F. Vitamin D deficiency in children in Aegean Region in Turkey. Cumhuriyet Med J 2015;37:17-22. DOI: 10.7197/cmj.v37i1.5000013903

17. Munot P, Krishnakumar D, Robb S, Davies T, Muntoni F, Manzur A. Prevalence of vitamin D deficiency in 157 boys with Duchenne muscular dystrophy. Arch Dis Child 2010;95:957-61. 
18. Bushby K, Finkel R, Birnkrant DJ, Case LE, Clemens PR, Cripe L, et al. Diagnosis and management of Duchenne muscular dystrophy, part 1: diagnosis, pharmacological and psychosocial management. Lancet Neurol 2010;9:77-93.

19. Bianchi ML, Mazzanti A, Galbiati E, Saraifoger S, Dubini A, Cornelio F, et al. Bone mineral density and bone metabolism in Duchenne muscular dystrophy. Osteoporos Int 2003;14:761-7.

20. Alshaikh N, Brunklaus A, Davis T, Robb SA, Quinlivan R, Munot P, et al. Vitamin D in corticosteroid-naïve and corticosteroid-treated Duchenne muscular dystrophy: what dose achieves optimal 25(OH) vitamin D levels? Arch Dis Child 2016;101:957-.

21. McDonald DG, Kinali M, Gallagher AC, Mercuri E, Muntoni F, Roper H, et al. Fracture prevalence in Duchenne muscular dystrophy. Dev Med Child Neurol 2002;44:695-8.

22. Larson CM, Henderson RC. Bone mineral density and fractures in boys with Duchenne muscular dystrophy. J Pediatr Orthop 2000;20:71-4.

23. Buckner JL, Bowden SA, Mahan JD. Optimizing bone health in Duchenne muscular dystrophy. Int J Endocrinol 2015;928385.

24. Looker AC, Mussolino ME. Serum 25-hydroxyvitamin D and hip fracture risk in older U.S. white adults. J Bone Miner Res 2008;23:143-50.

25. Bianchi ML, Morandi L, Andreucci E, Vai S, Frasunkiewicz J, Cottafava R. Low bone density and bone metabolism alterations in Duchenne muscular dystrophy: response to calcium and vitamin D treatment. Osteoporos Int 2011;22:529-39.

26. Fidan F, Berat MA, Tosun A. Pandemic era: vitamin D deficiency and insufficiency. Turk Osteoporoz Derg 2014;20:71-4. 